\title{
THE PRE-KETILIDIAN HISTORY OF THE GNEISSES NORTH-WEST OF FREDERIKSHÅBS ISBLINK, FISKENÆSSET REGION
}

\author{
A. M. Hopgood
}

\section{Introduction}

The geometry and field relationships of the gneisses and their associated rocks in the area immediately north-west of the Frederikshåbs Isblink reflect a complex intrusive, metamorphic and deformational history. All the rocks have been affected to a greater or lesser extent by amphibolite facies metamorphism and they comprise predominantly dark grey biotite and hornblende gneiss, together with thin anorthosites (mostly brecciated to white agmatites), intercalated striped green and dark grey amphibolite (sometimes garnetiferous), black hornblendites, garnet-kyanitesillimanite gneisses, sillimanite quartzites and pegmatitic pale creamy brown marbles and calc-silicate gneiss and fine-grained leucocratic gneisses. Early discordant layers include hornblendites, amphibolites, peridotites, silico-carbonatites and aplitic rocks.

Discordant bodies late in the deformational sequence of the complex appear to be confined to veins and dykes of quartz, quartzo-feldspathic pegmatite and aplite. The last basic intrusions are post-orogenic dolerites and lamprophyres.

The marbles outcrop within gneisses and while close proximity in the field can be demonstrated between the marble and anorthosite at one locality, and amphibolites and ultrabasics outcrop throughout the same general area as the marble, this is not consistently the case and no genetic relationship has been proved between these rock types. Preliminary trace element investigation indicates that the marble shows close affinity with rocks of sedimentary, rather than igneous derivation (F. Kalsbeek, pers. comm.). At several localities thin boudinaged bands of diopside which may represent the metamorphosed equivalents of thin marble bands are however, definitely associated with amphibolites. Furthermore, the association of the sillimanite and kyanite bearing rocks with the same amphibolites is certain and in the south-east a single isolated lens of marble outcrops in close proximity to these amphibolites and associated hornblendites. Some of the amphibolites may represent thin basic sills or lava flows, although there is no evidence for tops or bottoms or assymmetry of any other kind in the layering to support this. Structures in the present area, reminiscent of the 
bombs or pillows described by Windley (1968), are considered here to be the intrafolial remnants of detached fold hinges belonging to the earliest generation of folds recognised. Some of the apparently concordant hornblendites may represent ultrabasic concordant intrusives (thin sills) since they are frequently intimately associated in the field with peridotite pods varying in size from near spherical bodies less than a metre in diameter to masses over $200 \mathrm{~m}$ across. The pods and lenses which are often sheathed in bright green actinolite tend to show an alignment oblique to the foliation, which suggests they formed part of an originally continuous discordant tabular intrusion. This interpretation receives further support from the fact that one pod was found to contain a slab of marble.

\section{Deformational history}

It is not known for certain whether the first fold episode preceded the emplacement of the peridotite and the apparently concordant hornblendites although the relationship of form-lines to the alignment of the peridotite pods tends to suggest that this was so in the case of the periodotites. The commonest evidence of the first fold episode lies in the more or less ubiquitous presence in the gneisses and amphibolites of intrafolial detached isoclinal fold hinges. In some amphibolites garnet hornblendite relics of such structures have a tadpole-like appearance and bear a slight resemblance to structures in the Ravns Storø metavolcanics (Windley et al., 1966, p.9). The relationships between these folds and a second set of isoclinal folds are well displayed in three dimensions in the thin quartzofeldspathic layers weathered from within the marbles where small scale examples of both fold sets are well developed.

The earliest igneous event post-dating the $F_{1}$ folding appears to have been the intrusion of carbonatite or silico-carbonatite dykes of up to two metres wide. These highly deformed meta-carbonatites are mica (?biotite) sövites (Heinrich, 1966, p. 12); they have been seen only at two localities and cut the foliation associated with $F_{1}$ folding. One of the dykes cuts the foliation almost at right angles. It is itself cut by thin aplites subsequently deformed by $F_{2}$ isoclinal folding which at the same time imparted a faint $S_{2}$ foliation to the carbonatite. This foliation which is parallel to the axial planes of the $F_{2}$ isoclinally folded aplite veins lies at a high angle to the contact between the dyke and the host amphibolite. The fabric of the other dyke is derived from at least four sets of small scale folds, some associated with syntectonic mineral growth. The folds in this dyke are defined in some cases by discordant leucocratic veins similar to the aplites cutting the first dyke. Remarkably, both dykes have subvertical attitudes, one emplaced in the 'tadpole' amphibolite and the other in biotite quartzo-feldspathic gneisses. But for the complexity of their fabric coupled with the cross-cutting relationships of other intrusions their rectilinearity makes them appear at first sight to be com- 
paratively late igneous features, especially as one of them appears to have formed the focus of late movement associated with pseudotachylyte development.

The $F_{2}$ folded aplite veins which cross cut the carbonatite dykes are sometimes symmetrically zoned and rarely may contain scattered garnet. In the field they resemble the garnet 'rhyolitic' sheets of the Ravns Stor $\varnothing$ belt (Windley, 1968, p. 29) and may also be equivalent to the garnet aplite noted by Williams (internal report, GGU 1970). Also post-dating isoclinal folds are thin dark grey amphibolites whose discordance is only visible at fold hinges. Other early intrusions include lighter coloured, slightly coarser amphibolites with a mottled or flecked appearance, and these have been seen in one instance (in a block in agmatite) to cut dark grey amphibolite with a distinct angular discordance. The flecked amphibolite possesses what appears in some cases to be a relict ophitic texture. Cutting across the flecked amphibolites as well as the isoclinal folds is a series of fine grained, cement-grey, biotitic gneisses and these appear to have been folded both by isoclinal $F_{2}$ folds as well as by asymmetrical folds of the third generation. The close similarity in appearance as well as relative time of emplacement between the cement-grey gneisses and the $F_{2}$ folded aplites (described earlier as comparable to the Ravns Stor $\varnothing$ rhyolitic sheets) suggests that the two intrusives may be contemporaneous if not cogenetic.

$F_{2}$ folding appears to have been accompanied by boudinage of some basic bands, notably the thin dark green diopside layers associated with some amphibolites. These boudins which possibly represent the metamorphosed remnants of thin carbonate layers, have been reorientated subsequently by $F_{3}$ asymmetrical folding.

Two sets of moderately tight asymmetrical folds succeed the second (isoclinal) fold set. The orientation, and indeed the relative ages of these is difficult to determine but the fact that one set is often more or less recumbent suggests that it is likely to be the earlier of the two. $F_{3}$ folds are thus characterised by their recumbent attitude. Small scale $F_{3}$ folds are common throughout the area and they are invariably associated with migmatisation and the development or injection of autochthonous or parautochthonous quartzo-feldspathic veins parallel with their axial planes or with one series of fold limbs. These quartzo-feldspathic veins impart a strong but widely spaced foliation to the rocks. The syntectonic growth of aligned hornblende and biotite crystals within the fold axial plane has also imparted a weak but distinct $S_{3}$ axial planar foliation in some instances. The trend of the axes of these folds is commonly easterly and their axial planes often dip gently to the south-west. The axes were probably originally SSE but consideration of possible fold mechanisms shows that reorientation by later $\left(F_{4}\right)$ folds could have changed this to the commonly seen E-W direction. Because of the geometry and orientation of folds of this generation a particular horizon, such as an amphibolite layer, may outcrop intermittently over a wide area whenever it lies on the less steeply inclined long limb of the fold structure. 
$\mathrm{F}_{4}$ folds are asymmetrical, inclined and sometimes moderately tight. In general their axial planes dip east of south and their axes trend southerly or northerly but this trend, like that of $F_{3}$ but to a lesser extent, can be variable because of the geometry of the structures coupled with reorientation by later folding.

The effect of the refolding of $F_{3}$ by $F_{4}$ can be recognised at only a few places and is most clearly demonstrated when post- $\mathrm{F}_{3}$ and pre- $\mathrm{F}_{4}$ instrusions are present. The complex pattern arising from the refolding effects of all four episodes up to $\mathrm{F}_{4}$ can also be seen occasionally in the field although their mutual relationships are seldom clearly demonstrable.

Evidence of tight folding succeeding $F_{4}$ was not seen and the presence of such folds is not suspected. The next fold generation appears to be a series of upright, moderately tight folds trending ESE and the near parallelism of the axes of these $\left(F_{5}\right)$ and earlier folds suggests that the orientation of the earlier ones may have exerted some controlling influence on the attitude of the later set. $F_{5}$ folds are more or less symmetrical, depending on the pre-existing attitude of the foliation. The folding does not appear to have been accompanied by marked syntectonic mineral growth.

Prior to the onset of the fifth fold phase palingenesis affected the quartzofeldspathic gneiss and locally this was sufficiently intense to cause complete obliteration of the existing structure including the gneissose foliation, to produce a more or less homogeneous porphyroblastic rock of granodiorite to quartz diorite composition with only occasional relicts of amphibolite and hornblendite. Only rarely is there evidence to suggest that the rocks became significantly mobilised as a result of the palingenesis and the fact that, except on a small scale, relict folds and foliation appear generally to have been in no way disorientated serves to confirm this impression. The presence of some relict amphibolite folds still in their pre-palingenesis attitude as well as the gradual blurring of, and final obliteration of recumbent folds without disorientation testifies to the post-F $F_{4}$ relative age of the palingenesis. At one locality an apparent faint alignment of porphyroblasts parallel to a subvertical ESE-trending surface is due to slight shearing and granulation parallel to this direction and indicates that $F_{5}$ folding followed the palingenesis. Post-granitic pegmatites appear to be largely rectilinear and apparently therefore post- $F_{5}$ folding.

Later folds $\left(\mathbf{F}_{\theta}\right)$ trending SSE have caused some warping of earlier structures but because they are comparatively open structures (on upright axial planes trending approximately $160^{\circ}$ ) their orientation effects are only moderate. Because of their open nature the relationship between these structures is not easily seen except on a few outcrops where the ESE $F_{5}$ folds can be seen to have undergone some reorientation by the later SSE folds.

The latest folds are in the form of broad open arches and troughs whose trend is on average $020^{\circ}$. As far as can be determined they have more or less vertical axial surfaces although their attitude is difficult to gauge because of the 
extremely open nature of these warps. Their form is most easily recognised in those cases where near horizontal quartzo-feldspathic pegmatites emplaced parallel to the axial surfaces of the earlier recumbent folds provide simple planar structural surfaces which have been gently warped during $F_{7}$ folding. Geometrically the relationship between earlier folds and the latest warps $\left(F_{7}\right)$ is a complex one and is usually difficult to determine in the field.

The latest major structural features recognised, a series of low angle thrust surfaces associated with pseudotachylyte veining, are considered to be the latest important structures in the orogenic history of the area. These surfaces trend north-east and dip south-east subparallel to the general foliation attitude suggesting overthrusting from the south-east.

While it would be premature at this stage, in view of the structural complexity, to attempt to define the stress fields related to each fold generation the following are tentative suggestions.

\begin{tabular}{lcl}
\hline Phase & Axial Planar Strike & \multicolumn{1}{c}{ Stress } \\
\hline $\mathrm{F}_{1}$ & $\mathrm{NE}$ & Unknown \\
$\mathrm{F}_{2}$ & $\mathrm{NE}$ & Unknown \\
$\mathrm{F}_{3}$ & $\mathrm{NE}$ & $\begin{array}{l}\text { Unknown (possibly N-S compres- } \\
\text { sion with overthrusting from the SE) }\end{array}$ \\
$\mathrm{F}_{4}$ & ESE-SE & NW-SE compression with over- \\
& & thrusting from the SE. \\
$\mathrm{F}_{5}$ & $\mathrm{ESE}$ & NNE-SSW compression \\
$\mathrm{F}_{6}$ & $\mathrm{SSE}$ & ENE-WSW compression. \\
$\mathrm{F}_{7}$ & $\mathrm{NNE}$ & WNW-ESE compression. \\
NE-trending thrusts & & NW-SE compression and over- \\
& & thrusting from the SE. \\
\hline
\end{tabular}

\section{Large scale structures}

In the field and especially on a detailed geological map of the area, the large scale expression of many of the fold generations can be recognized with a fair degree of certainty, although with the exception of the last three episodes, whose style and trends are not greatly affected by reorientation, there is a certain amount of ambiguity regarding their classification. Only a few larger structures are shown by the different lithologies on the simplified preliminary map accompanying this issue, and these are not given in chronological order.

The generally north-eastern trend of the main lithological units appears to be 
controlled by the trace of the isoclinal $F_{1}$ and $F_{2}$ fold axial planes and most of the undulations in this trend arise from warping by the final three fold episodes, particularly the SSE trending $F_{6}$ and the ESE-trending $F_{5}$ because these directions are nearly perpendicular to the major litho-structural trend whereas the NNE-trending $F_{7}$ is close to parallel to the $F_{2}$ north-eastern trend and its effects are less likely to be discernible. Distinction between $F_{5}$ and $F_{6}$ on a large scale is difficult because of mutual interference. The latest folds are most clearly seen on a form-line map where the effects of the topography on the outcrop distribution are less inclined to obscure the traces of these relatively gentle open structures. The pattern on the form line map is not normally influenced by closures of isoclinal $F_{1}$ and $F_{2}$ folds and is not much affected by $F_{3}$ and $F_{4}$ folds. On the other hand the lithological map shows the effects of $F_{1}$ and $F_{2}$ folds and provides the only reasonably certain means of discerning the $F_{3}$ and $F_{4}$ folds. These two inclined, or near recumbent folds are extremely difficult to separate on the large scale as well as small scale because of mutual interference and it is only occasionally that $F_{3}$ folds can be distinguished from $F_{4}$ folds. They show in a large folded amphibolite in the north of the area close to the inland ice and in the tight folding which survived granitisation in the central southern part of the area. The best example of the effects of large scale $F_{5}$ folding appears in the north and north-west of the area where a $F_{2}$ axial trace swings from the folded marble south-west into the granodiorite. Between the marble and the granodiorite a broad flexure arising from $F_{5}$ as well as cross-folding by $F_{6}$ is visible on the map and north of the marble a swing in strike due to $F_{5}$ folding is again evident. Subsequently this has been affected by later SSE $F_{6}$ folding. Although single large scale late NNE warps are visible in the field, the only structural effect visible on the map likely to have arisen as a result of the last fold phase is a gentle curvature of the granodiorite outcrop to the north-west of the centre of the area and to the south-west of the closure of the folded marble referred to above. Here the strike swings away from the $F_{2}$ fold outlined by the granodiorite about a line trending approximately NNE parallel to $F_{7}$.

\section{References}

Heinrich, E. W. 1966: The geology of carbonatites. Chicago: Rand McNally \& Co.

Williams, H. R. 1970: Preliminary report of field work in the Fiskenesset region. Area 8. Internal report GGU.

Windley, B. F., Henriksen, N., Higgins, A. K., Bondesen, E. \& Jensen, S. B. 1966: Some border relations between supracrustal and infracrustal rocks in South-West Greenland. Rapp. Grønlands geol. Unders. 9.

Windley, B. F. 1968: New field relations from the early Precambrian of West Greenland. Rapp. Grønlands geol. Unders. 15, 27-31. 